\title{
The dynamics of Covid-19: weather, demographics and infection timeline
}

\author{
State University of Campinas (Unicamp) \\ Campinas, São Paulo, Brazil \\ pedrosa@unicamp.br
}

Renato H. L. Pedrosa

\begin{abstract}
We study the effects of temperature, absolute humidity, population density and when country/U.S. state reached 100 cases on early pace of Covid-19 expansion, for all 50 U.S. states and 110 countries with enough data. For U.S. states, weather variables show opposite effects when compared to the case of countries: higher temperature or absolute humidity imply faster early outbreak. The higher the population density or the earlier the date when state reached $100^{\text {th }}$ case, the faster the pace of outbreak. When all variables are considered, only population density and the timeline variable show statistical significance. Discounting the effect of the timeline variable, we obtain an estimate for the initial growth rate of Covid-19, which can be also used to estimate the basic reproduction number for a region, in terms of population density. This has policy implications regarding how to control the pace of Covid-10 outbreak in a particular area, and we discuss some of them. In the case of countries, for which we did not have demographic information, weather variables lose statistical significance once the timeline variable is added. Relaxing CI requirements, absolute humidity contributes mildly to the reduction of growth rate of cases for the countries studied. Our results suggest that population density should be employed as a control variable and that analysis should have a local character, for subregions and countries separately, in studies involving the dynamics of Covid-19 and similar infectious diseases.
\end{abstract}

Keywords: covid-19, daily growth rate, reproduction number, weather, population density, infection timeline.

\section{Introduction}

The first reported cases of what was later denominated Covid-19, caused by new virus of the group Coronaviridae, occurred in China during the last month of 2019. Cases soared during the second half of January, going from 80 on January $18^{\text {th }}$ to over 9,000 by the end of the month, when there were 14 cases reported in Japan and only a few other across Asia and only 7 in the United States. By mid-February, there were cases in many other countries, but still in relatively small numbers, and none in Africa or South America, which have most of their territories in the Southern Hemisphere, then under Summer. By the end of that month, some countries, besides China, were already facing an epidemic situation. The first positive case reported by a South American country occurred on Feb. $26^{\text {th }}$, in Brazil. Since then, the virus started to spread, slowly, with all cases being of people arriving from other countries, especially from Italy, or who had direct contact with them. By March $6^{\text {th }}$, it was recognized that local untraceable transmission was occurring in Brazil and the number of cases grew rapidly. As we will see, the pattern, for the 10 
high degree, with varying growth rate values. During the whole period since the start of the pandemic until the end of March, weather in Brazil has been warm and humid, with temperatures frequently soaring above $32 \mathrm{C}$ and absolute humidity never below $10 \mathrm{~g} / \mathrm{m}^{3}$. This raised the possibility that warm and humid weather will not help contain the spread of the virus, as is typical of many viral diseases $(1,2,3,4,5)$. There are various studies with early, somewhat conflicting, results on those relationships for Covid-19 $(6,7,8,9,10,11,12,13)$, as discussed in the NASEM report (14). This study proposes to expand the analysis to include, besides weather information, demographic (population density) and the timeline of outbreak (date of $100^{\text {th }}$ case) as variables. The idea that higher population density would increase the growth rate of Covid-19 is expected (15), the research we are reporting helps understand how e by how much.

Besides weather, there has been also a wide range of estimates of the basic reproduction number $R_{0}$ of Covid-19, the average number of people infected by an infectious person, from 2 to over 6, not including CI's, all based on the early data from China (16). We will see that population density must be taken into account and may help explain the variability of $R_{0}$, as it impacts the estimate of early daily growth rate of the disease, used in many of those estimates.

We develop multivariable linear models in which the dependent variable is the early daily growth rate of Covid-19, which has been estimated by the coefficient of the best exponential fit to the evolution curve of cases in the period of 10 days starting on the date when region reached the $100^{\text {th }}$ case. It will be denoted by $k$. The control variables are: average temperature and absolute humidity values during the 25 days starting 15 days before the region reached the $100^{\text {th }}$ case; the date when the $100^{\text {th }}$ case occurred; and the (log of) population density for the counties with higher participation in the spread of Covid-19 (for U.S. states only). We find that weather variables, albeit significant in some of the single-variable models (but with opposite effects for the two groups of regions, U.S. states and countries), lose significance when the timeline and/or demographic variables are introduced. In the first case, for states and countries, the later the date of the $100^{\text {th }}$ case, the slower the initial pace of expansion of Covid-19. In the second one, the higher the population density U.S. states, the faster the disease has spread in its initial phase. The model with both variables, only available in the case of U.S. states, furnishes the best estimates, explaining $71 \%$ of the variability of the early daily growth rate $k$. In the case of countries, if one relaxes statistical requirements, absolute humidity (together with date when country reached the $100^{\text {th }}$ case) shows a small positive impact on the early daily growth rate of Covid-19, but we do not expect even that small effect to remain once one includes population density and possibly other variables in the model.

Discounting the effect of the date of $100^{\text {th }}$ case, we obtain an estimate of the initial daily growth rate of cases of Covid-19 as a function of population densities of U.S. states. The relation is given by

$$
N_{i} \propto e^{\kappa t} * P D_{i}^{\alpha t}
$$

where $P D_{i}$ is the population density of region, $\kappa, \alpha$ are universal constants (not depending on region), which are derived from our analysis. A similar model should hold for regions in other countries, which may be verified by further studies, possibly with different parameters. It would also help explain part of some unexpected behavior among countries and among subregions and cities within a country and would be useful for policy decisions regarding how to develop adequate social distancing measures. We end our study by developing a preliminary relationship 
between the basic reproduction number of Covid-19 and population density, derived from results of models developed in our analysis.

The timeline variable, the data when the region reached the $100^{\text {th }}$ case, is likely a proxy for early social distancing practices, even before government measures are put in place, so that it actually depends on how the population perceives the dangers of the infection and how governments respond to it, sometimes even before the first cases had been detected, but after the infection had shown that it could become a health issue. It may also be related to other societal variables, such as number of persons per dwelling (crowding), intensity of use of mass public transportation, income, education, etc. Population density is an independent variable that impacts the general rate of expansion of Covid-19 and, possibly, if lower, makes distancing measures easier to implement and maintain, helping the control of its growth rate.

\section{Data and methods}

\section{Confirmed Covid-19 cases}

Databases of reported cases of Johns Hopkins University's Center for Systems Sciences and Engineering (CSSE/JH) (17) for U.S. states, of the European Centre for Disease Prevention and Control (ECDC/EU) (18) for countries.

\section{Weather data and averages of temperature and absolute humidity}

NOAA Integrated Database (ISD) (19) of meteorological observations, through the R package "worldmet" (20). For countries, we used the station nearest to the capital with $100 \%$ coverage, when available. In the case of the United States, data for the main airports in Seattle, San Francisco and New York City. For U.S. states, the data from main airport in the largest city in the state. For Brazil, data for the main airports of São Paulo and Rio de Janeiro. From NOAA weather data, the absolute humidity $A H\left(\mathrm{~g} / \mathrm{m}^{3}\right)$ is computed from temperature $T(\mathrm{C})$ and relative humidity $R H(\%)$ using an approximation formula derived from the Clausius-Clapeyron equation $(8,21,22)$,

$$
A H=\frac{13.247}{273.15+T} * R H * \exp \left(\frac{17.67 * T}{T+243.5}\right)
$$

The averages for both variables were computed during the period of 25 days starting 15 days before the day the region reached the $100^{\text {th }}$ case, covering a span of two weeks before confirmation and the next 10 days used to estimate the exponential coefficient for the evolution of cases. The above equation shows that $\mathrm{AH}$ depends exponentially on $\mathrm{T}$, to a high degree, for constant RH, in the usual range of values of temperature. This may be seen in Fig. 6 and will have impact on our models.

\section{Countries and U.S. states}

We have considered the 110 countries and that had at least 10 days of data starting when they had reached the number of 100 accumulated cases, end-date being at most April 10 $0^{\text {th }}$. All 50 U.S. states had already reached that stage by that date.

\section{Population density of U.S. states and counties}

All data used is for $2019(23,24)$. We tested three variables linked to county population density in the U.S.: density of the densest county and (weighted) average of densities of counties 
which responded for at least $60 \%$ of the cases in a state, in both arithmetic and geometric versions. The last two cases provided the best fitting, very close in results. Regarding the density of densest county in a state, there are too many exceptions where they are not the main contributor to the early spread of Covid-19. For example, in California, Santa Clara, San Mateo, San Diego and Los Angeles had higher early numbers of cases compared to San Francisco, the densest county in the state. Similarly, Westchester county was a very important contributor to the number of cases in New York State, later surpassed by New York City county, but it is over 30 times less dense than the latter ( 867 to $27,775 \mathrm{pop} / \mathrm{km} 2$, respectively). We will see how that is related to the growth rate of Covid-19 in those two areas. After some testing, we decided to use the arithmetic weighted averaging of densities, i.e., the usual aggregate density which is computed by the ratio between total population and total land area of all counties involved, as it provided slightly better fitting properties in relevant models.

We have employed as control variable the natural logarithm of density. Density enters econometric analysis via its log-transformation $(25,26)$ and it is also typical to apply log to variables of concentration in chemistry, like in the computation of $\mathrm{pH}$, and in other fields. In health-related studies, it is also usual to use logarithm of density (27). In epidemiology, carefully modelling the dependence of the basic reproductive rate $\left(R_{0}\right)$ of infectious diseases on population density (28) shows that one must use non-linear scaling when dispersion is high, which is the case here, as population density is concentrated on smaller values (Fig. 1.f). As we analyzed various options of transformations, both in terms producing a more evenly spread distribution of the variable and of our model fitting, it turned out that the $\log$-transformation of population density showed not only good distribution properties (Fig. 1.g), but proved to be well adapted as a control variable in the models.

\section{Growth rate of number of cases}

We considered the period of 10 days starting on the day the number of cases reached 100 and computed a simple linear regression for $\log \left(N_{i}\right)$ as function of day $(t)$, where $N_{i}$ is the number of accumulated observed cases for region $i$ at a given day of the period, given by the model

$$
\log \left(N_{i}\right)=C_{i}+k_{i} * t+\varepsilon_{i}
$$

The growth rate variable, the dependent variable in the models we develop, is the estimated $k_{i}$, the initial daily growth rate of cases of Covid-19. We have also checked 12-day and 15-day windows starting on the 100th-case day, but there was no relevant impact on the results of the models. We preferred the 10-day window as it provided the best fitting parameters for models given by Eq. 3. We have also estimated the growth rate using endpoints, but we wanted to be able to check the fitting of evolution curves to an exponential and if that affected results. Also, sudden jumps in the reported number of cases cause similar jumps of endpoints estimate, while the regressed estimate follows a smoother path. The choice of day of 100 accumulated cases is related to when it is expected that local transmission would be under way, as that is when an exponential increase is expected to start. When states/countries reach 100 cases, there are already a few communities with at least 20 cases; it has been estimated that when a U.S. county has reaches 20 cases, the chances that there is ongoing local transmission are $99 \%(29,30)$. For example, for the United States as a country, the date of the $100^{\text {th }}$ case was March $3^{\text {rd }}$, when Washington and California led the country, with 27 and 25 cases, respectively, concentrated in King County and counties around San Francisco, respectively. Within the 10-day period used in the estimation, 
New York had also become a hotspot of cases, and on the last day of the 10-day period, it was second in number of cases, and other states had surpassed 20 cases.

\section{Hypothesis on $k_{i}$}

For the estimate $k_{i}$ to be representative of the speed of transmission of the novel coronavirus in a community we need, first, that the way the cases were accounted for did not change significatively along the 10-day period used for the models. The evidence from the estimates corroborates that assumption, as the values of $R^{2}$ for regressions (1) are mostly above 0.95 (Figs. 1.b, 2.b); secondly, that the number of positively tested cases of people with various levels of symptoms, or of hospitalized cases, are constant fractions of the total number of people infected (of which, many, are asymptomatic). Some countries have tested all people with any symptom, others only those hospitalized (the case for Brazil), and others with in-between levels of symptoms. The estimated $k_{i}$, under those two hypotheses, would not depend on the alternatives considered by different countries (or states) regarding how they measured confirmed cases.

\section{Modelling the early dynamics of Covid-19}

Using the data described above, we consider the following linear regression model for the U.S. states:

$$
k=C_{0}+C_{1} * A v T+C_{2} * A v A H+C_{3} * D a y_{100}+C_{4} * \log (P D)+\varepsilon
$$

where $k$ is the exponential growth rate coefficient estimate (Eq. 3), $A v T$ is average temperature, $A v A H$ is average absolute humidity, Day $y_{100}$ is the date when state reached the $100^{\text {th }}$ case and $P D$ is the population density variable described above. For the collection of 110 countries we use the same model without the last regressor. For both cases, average temperature and absolute humidity show high levels of association (Fig. 6), so that we have to be careful when using both variables in the same model. We will further discuss those points in the variables and modelling sections below. Before we move on to analyzing the data and models, we observe that we have also considered another timeline variable, given by the number of days between the occurrence of the $1^{\text {st }}$ and the $100^{\text {th }}$ case, but it did not introduce any new statistically relevant insight into the analysis, so we have opted to leave it out in the final version of the paper.

Software: $R$, worldmet package.

\section{Preliminary analysis}

\section{Variables}

The dependent variable given by the initial daily growth rate $k$ shows appropriate distribution properties, which may be seen from Figs. 1.a and 2.a. That allows us to go forward with traditional linear regression models, without need for transforming that variable or using GLM. We see that $k$ is spread along a very wide set of values, from almost 0 to 0.4 . For countries, mean $=0.169$, median $=0.155$ and $\mathrm{SD}=0.082$. For U.S. states, mean $=0.209$, median $=0.215$ and SD $=0.068$. Fig. 3 has the evolution of $k$ for the four states with earliest date of the 100th case, which have some outlier behavior regarding our models, as will be explained later, California, Massachusetts, New York and Washington. We observe that the first three states in that group show a peak for the values of $k$ that do not coincide with date which we used to start 
the 10-day window for calculating the value of $k$ for that state. This will be further discussed when we develop our models to isolate the effect of population density on the early daily growth rate. Washington shows a pattern which is similar to that of most other states, with a monotonously decreasing trend for $k$ from the start, which would seem to be associated to some early attenuation of growth, even though it was the first state to reach 100 cases.

The values of $R^{2}$ for regressions employed to estimate $k$ (Eq. 3) were typically above 0.90 and most above 0.95 (Figs. 1.b, 2.b). In the case of U.S. states, $R^{2}>0.90$ in all cases. For countries, there were a few cases for which the regressions following Eq. 3 with $R^{2}$ below 0.90 . To visualize how well the exponential model for the growth rate $k$ fits the actual trajectories, Fig. 4 displays the exponential prediction and the curves for actual accumulated number of positive Covid-19 cases, for selected countries, including eight of the eleven countries that had $R^{2}<0.90$ and another group with $R^{2}>0.95$. It is interesting that there is little qualitative difference between the two groups of countries, except for the case of Denmark, which had $R^{2}=0.74$, the lowest among all countries. From the group of those countries with relatively low values for $R^{2}$, it seems that lower values of $k$ tend to come from cases with lower $R^{2}$ as well, but we saw no such trend for all values of $R^{2}$, so we decided not to restrict the set of countries in the study based on that variable. Testing the models without Denmark did not brought up any new statistical behavior, so we kept it in all models.

Figs. 5.a-d show the daily behavior of average temperature and absolute humidity, along the 25-day periods used to estimate the initial growth rate for U.S. states and countries. Figs. $6 \mathrm{a} / \mathrm{b}$ show that there is strong exponential association between the two variables. The squares of correlation for the exponential trend lines are above 0.85 in both cases, and with a few outliers removed, above 0.89 for countries and above 0.92 for U.S. states (shown in the graphs). This is expected, as Eq. 2, for constant relative humidity, is closely approximated $\left(R^{2}>0.99\right)$ by an exponential of temperature in the usual natural range of values of temperature. For linear trend lines, $R^{2}$ is above 0.80 in all cases. These results imply that we should be careful when employing both variables in the same model, as we will see below, in the modelling section. Figs. 7.a-d present how temperature and absolute humidity relate to when state/country reached the $100^{\text {th }}$ case. We see they follow opposite trends for the two groups, a fact that will help explain I part why the timeline variable, when added to models, reduces the impact of the weather variables.

For the date when state/country reached the $100^{\text {th }}$ case, China, among countries, shows a strong outlier behavior, as it did so on Jan. $19^{\text {th }}$, more than a month before any other country (Fig. 2.e). We present models with and without China, whenever that variable was involved, even though the impact of that was minimal. In the case of the variable of date when state reached the $100^{\text {th }}$ case, there are four states (California, Massachusetts, New York and Washington) which showed outlier character, as they were the first to reach that stage (seen clearly in Fig. 9.c, but also in Fig. 10). Removing those four states did not change the overall behavior of models, but improved estimates in all models in which it was included. For all quantitative analyses we have employed the models with the restricted set of states, omitting those four states.

Population density was used in log-transformation, as already discussed. We recall that density was computed as the aggregated density of counties which contributed with at least $60 \%$ of the cases along the 10-day window used to estimate the daily growth rate $k$, for each state. There was only one exception, that of Idaho. Using the above criterion, data from two counties would be employed, Ada and Blaine. Ada is the densest county in the state, with a population of 482,000 and density of $178 \mathrm{pop} / \mathrm{km}^{2}$, while Blaine is a mountain tourist area with 23,000 population and density of only $3.4 \mathrm{pop} / \mathrm{km}^{2}$. As of Apr. $10^{\text {th }}$, Blaine had 19.4 cases per 1,000 pop., 
Ada, 1.03, Canyon, 0.60, and Kootenai, 0.25 . Because of that disparity, and the special situation of Blaine County, which had in the tourist inflow a probable cause of the high intensity of infection, we decided to use density of Ada County as the density value for Idaho. Overall, that choice did not change the estimates and models, but, when we later adjust growth rate by day of $100^{\text {th }}$ case and then compute the level of expected daily growth rate for Idaho in terms of density, that would impact the state's final estimate in a significant way.

Fig. 8 shows the evolution curves of cases for U.S. states for the 10-day period used to estimate the growth rate $k$, by temperature. It shows that there is a wide range of values of $k$, and no obvious trend in the temperature averages w.r.t. $k$. The analogous graphs for absolute humidity, and for countries, not included, are similar.

\section{Models: technical aspects}

Models based on Eq. 4 are presented in Tables 1 and 2 for U.S. states and countries, respectively. The intervals for coefficients use $95 \%$ CI. We omit the values of intercepts, as they are not relevant for this part of analysis. We include $F$-statistic $p$-values for the multivariable cases and Shapiro-Wilk test results for the residuals of all relevant regressions. In the case of multivariable regressions, $R^{2}$ is the adjusted value.

\section{U.S. states}

Table 1 presents the results of regressions for the exponential growth constant $k$ and regressions for timeline variables w.r.t. population density for U.S. states. As the qualitative behavior of models employing all states is the same as that excluding the states which have outlier behavior in relation to the regression of $k$ w.r.t. the timeline variable of data of the $100^{\text {th }}$ case, and all regressions with this restricted set show sharper estimates, we have presented only those models. Model 1 shows that only the date of the $100^{\text {th }}$ case and density have statistical significance in the complete model. Since it includes both weather variables, and they could be interacting and increasing their p-values, given their high level of collinearity (discussed above), we have Models $2 / 3$ with only one of them included. Again, the weather variables show high p-values. Model 4 is the only multivariable model for which all variables have coefficients rejecting the null hypothesis and will be the basis for discussion developed below.

Model 9 present the association of the relevant timeline variable and population density. Even though the association is very intense, one must note that both variables survived in Model 4 , indicating that there are effects of each which cannot be explained by the other, regarding impact on the early daily growth rate of Covid-19.

\section{Countries}

Models $1 / 1^{\dagger}$ in Table 2 show that the variable $\operatorname{Day}_{100}$ is the only one statistically significative in the complete model. Model $1^{\dagger}$ omits China, as explained earlier. The 1-variable models show p-values below 0.05 , but one must note that the residuals, in the cases of the weather variables, both cases, have low p-values in the Shapiro-Wilk test. An inspection of scatter plots in Figs. 11.a-b does not provide obvious choices of countries that would be generating the nonnormality of the residuals. Model 2, for $D a y_{100}$ and $A v A H$ as control variables, may be considered relevant, once the $\mathrm{CI}$ requirement is relaxed, as we discuss below. 


\section{Models: consequences and discussion}

\section{U.S. states}

We discuss the results of Model 4 in Table 1, which shows that variables Day $y_{100}$ and $\log (D P)$ explain about $71 \%$ of the variability of the early daily growth rate estimate for U.S. states. The coefficient of Day 100 implies that if a state reached 100 cases 10 days after another one, one would expect $k$ to be reduced by 0.08 point, which would impact significantly the pace of spread of Covid-19. For example, reducing $k$ from 0.30 to 0.22 , for two states with same population density value, the expected number of days to double the number of cases would increase from 2.3 to 3.2. Keeping those rates and starting from 100 cases, after one month the first state would have reached 810,000 cases, while the second, 74,000.

The value of the population density coefficient implies that doubling density would cause an expected increase of the value of $k$ by $0.0212 * \log (2)=0.0147$ point. For example, the states of Iowa and Missouri, which reached the $100^{\text {th }}$ case on Mar. $23^{\text {rd }}$, had $k$ 's estimated as 0.195 and 0.235 , respectively, thus a difference of 0.040 . Their population densities are 290 and 1,991 pop $/ \mathrm{k}^{2}$, respectively, which imply an estimated increase of 0.041 point in the value of $k$, or almost exactly the actual difference. The scatter plots in Fig. 9 make it clear how $D a y_{100}$ and $P D$ variables are better associated to the variability of $k$ than the weather ones.

The one-variable models for weather variables show an unexpected result, as both are positively associated to $k$ in this case. But from Figs. 7.a-b, that behavior is in part caused by a late entry of the disease in colder and drier states, some with low population density values. But the results of Model 4 imply that the population density alone does not explain the variability of $k$. We further observe that, by themselves, the explaining power of Day $_{100}$ and population density, in relation to growth rate of Covid- 19 , are about the same ( $65 \%$ and $62 \%$, respectively, Models $7,8)$. Thus, there are still other aspects impacting when state reached the $100^{\text {th }}$ case, along with population density (Model 9), possibly early measures of social distancing, many independent of government measures, such as people washing hands frequently, avoiding crowds and physical contact, restricting travels and circulation, etc., besides some societal and interpersonal contact practices. We see the timeline variable a likely candidate for a proxy of early social distancing initiatives and characteristics of societal and personal interactions in a region.

From Model 9, doubling the population density would make the day of $100^{\text {th }}$ case happen about $2.49 * \ln (2)=1.7$ days earlier. The scatter plot for these two variables (Fig. 10) shows that the states which had their outbreaks starting earlier, California, Massachusetts, New York and Washington, also show some outlier behavior in this case (especially the latter), as in the case of the association between $k$ and the timeline variable (Fig. 9.c). The effect of population density on the date of $100^{\text {th }}$ case is expected, as not only lower population density slows the pace of contagion, as we have seen, but one may also think that the introduction of the virus would have been delayed in such states, due to lower traveling intensity to those areas (with the obvious exceptions of low-density areas with high level of tourist interest, as we have seen in the case of Idaho). 


\section{Countries}

According to Table 2, the date when the $100^{\text {th }}$ case occurred is the only significant variable for countries. Models $5 / 5^{\dagger}$ say that, for each 10 days of delay in that occurrence, the value of $k$ is expected to be reduced by 0.045 ( 0.051 , for model without China), which is a smaller effect as in the case of U.S. states $(0.080$, Model 4 , Table 1$)$. This is likely due to the presence of outliers which we have not removed, like Japan and Singapore (see Fig. 11.c) and possibly others, which reduces the absolute value of the coefficient. Nevertheless, if we use the confidence interval for both coefficients, they cannot be considered statistically different.

Individually, weather variables show significative negative association with the pace of Covid-19 expansion, as already noted, a result that have been widely reported in other studies. In part, the reduced effect of the weather variables in the multivariable models including Day 100 could be explained by the plots and trend lines in Figs. 7.c-d, which show that the countries starting their outbreaks later showed higher temperatures and more humid weather. But, as we saw in the case of U.S. sates, the fact that weather variables may be associated with the date of the $100^{\text {th }}$ case cannot be used to reduce the impact of the timeline variable on the early growth rate of Covid-19, indicated in all multivariable regressions. Relaxing CI requirements, models $2 / 2^{\dagger}$ show that, for countries with same date of $100^{\text {th }}$ case, increasing absolute humidity by $10 \mathrm{~g} / \mathrm{m}^{3}$ would reduce the value of $k$ by about 0.02 point. That is a relatively small effect and would not severely impact the actual growth rate of Covid-19. Fig. 11 presents the scatter plots for $k$ and control variables.

\section{Isolating the effect of population density}

Using the results of Model 4 in Table 1, it is possible to remove the effect of the date when the state reached the $100^{\text {th }}$ case and estimate how population density impacts the initial daily growth rate of Covid-19 infection. From the value of the coefficient, one would expect that for every day we move a state from its original date of the $100^{\text {th }}$ case, $k$ would increase by 0.008 point. We use the coefficient of Day 100 from Model 4 and bring all states back to March $7^{\text {th }}$, the date when Washington reached the $100^{\text {th }}$ case, the first U.S. state to reach that milestone. Following that methodology, we present, in Table 3, the results of the regression of the adjusted $k$ w.r.t. population density. Figure 12 displays the scatter plot of the adjusted growth rate and population density, with the $95 \%$ CI band.

The four states which were not part of the regressions employed along the process, including Massachusetts, are displayed in red. Disks use the adjusted values of growth rates, the triangles are adjusted for date of $100^{\text {th }}$ case from maximum values observed in the Figs. 3.a-c, the local maxima for California, Massachusetts and New York. In the case of Washington, as there is no local maximum in the graph for the evolution of $\mathrm{k}$ (Fig. 3.d), we did not perform any further correction, but it seems plausible, from the early behavior of the daily growth rate indicator, that the value we used for Washington is underestimated as well.

This is as close as we can get to estimate the relationship between a well-known independent variable and how Covid-19 would develop initially. We may now estimate the parameters $\kappa, \alpha$ in Eq. 1,

$$
N_{i} \propto e^{\kappa t} * P D_{i}^{\alpha t}
$$


medRxiv preprint doi: https://doi.org/10.1101/2020.04.21.20074450; this version posted May 10, 2020. The copyright holder for this preprint (which was not certified by peer review) is the author/funder, who has granted medRxiv a license to display the preprint in perpetuity.

It is made available under a CC-BY-NC-ND 4.0 International license .

where $P D_{i}$ is the population density of U.S. state $i$. From the model in Table 3, one has

$$
k_{\text {adj }}^{(i)}=0.2135+0.0212 * \log P D_{i}
$$

so that

$$
N_{i}=N_{0}{ }^{(i)} * \exp \left[\left(0.2135+0.0212 * \log P D_{i}\right) * t\right]
$$

where $N_{0}{ }^{(i)}$ is the number of cases on Day ${ }_{100}$ for state $i$. Eq. 1 follows from (6) with $\kappa=0.2135$, $\alpha=0.0212$. One would need to use the confidence intervals for these parameters, as given in Table 3, for a full estimate of the dependence of the initial evolution of cases on population density of state. In fact, one should include the intervals for the estimates of the adjusted $k$ as well, which would introduce further uncertainty. The adjusted values and population density are plotted in Fig. 12, with 95\% CI band. Any practical application of the above estimates regarding social distancing should be carefully confronted with actual field conditions and adjusted accordingly to actual response to adopted policies.

\section{Daily growth rate, population density and basic reproduction number}

It is possible to relate the values of $k$ to the basic reproduction number of an infectious disease, $R_{0}$, the estimate of the average number of new infections generated by an infectious person $(31,32)$, which has been subject of much investigation since the start of pandemic (16). With that in hand, Eq. 5 would provide the link to population density. For example, using a SEIR epidemiological model (32),

$$
R_{0}=1+k v+f *(1-f) *(k v)^{2},
$$

where $v$ is the serial interval and $f$ is the ratio between latent period and serial interval, we see that, at least from an empirical viewpoint, $R_{0}$ depends quadratically on the logarithm of population density, since the daily growth rate shows good (empirical) linear dependence on density (Eq. 5).

For a state with low density, say $25 \mathrm{pop} / \mathrm{km}^{2}$, the adjusted $k$ would be in the interval $[0.210,0.354]$, and $R_{0}$, in the interval [3.1,5.2], using the parameters in Eq. 7 from $(v=7.5$ days and $f=0.307$ ) and our estimates for the daily growth rate without any social distancing in place. For a state with high density, say $1,600 \mathrm{pop} / \mathrm{k}^{2}$, adjusted $k$ would be in $[0.264,0.477]$ and $R_{0}$, in $[3.8,7.3]$. For New York City county, at $27,775 \mathrm{pop} / \mathrm{km}^{2}$, if the model applies, one would have a range for $k$ between 0.301 and 0.561 (the measured maximum was 0.511, see Fig. 3.c), and for $R_{0}$, between 4.3 and 9.0. For Westchester, which has $P D=867 \mathrm{pop} / \mathrm{km} 2$, the estimated interval for $\mathrm{k}$ would be $[0.256,0.357]$ (the measured maximum was 0.345 , Fig. 3.c), the interval for $R_{0}$ would be $[3.7,7.0]$.

These values are higher than the ones estimated in (33) (baseline $=2.2$ ), since they used a much lower estimate for the initial daily growth rate of Covid-19, of 0.10 , estimated employing the very early phase of the disease in Wuhan, up to Jan. 4. Other estimates, using growth rates for a later period, much higher, have values closer to ours (34). These estimates have relevant implications for the amount of social distancing required to control the infection cycle. Basic epidemiological theory says that the force of infection should be reduced by $1-1 / R_{0}$ to achieve extinction. An $R_{0}$ of 3.1 would require a reduction of $71 \%$; if it is 7.3 , the required reduction would be $86 \%$; if it is $9.0,89 \%$. These estimates are in line with what has happened in many 
places, as it is proving much harder to extinguish Covid-19's infection cycle than originally estimated.

We observe that the above intervals for $R_{0}$ are possibly wider, as we would need to consider the intervals for $v$ and $f$ as estimated in (33) and, as mentioned above, some extra variability coming from Model 4 in Table 1, used to compute the adjusted $k$. The above discussion is just a simple preliminary exercise indicating how population density enters the picture of estimating the basic reproduction number of Covid-19. Further studies regarding the estimation of parameters used to compute the basic reproduction number from initial daily growth rate would help establish its association with population density on firmer ground. One may also conjecture that there are underlining mathematical models directly relating $k$ and $R_{0}$ to population density, which would provide better alternatives to establishing their relationship. Our empirical relationships could help check the adequacy of different models. Probably, we are just looking at first- and second-degree approximations of those relationships, which are reasonably adequate for the range of empirically available data.

The above models relating the early daily growth rate and basic reproduction number of Covid-19 to the variables of infection timeline and population density have shown similar results on a preliminary analysis of a set of U.S. counties with enough data and will be the subject of a follow-up paper (35), which will also discuss the case of Brazilian states.

\section{Final comments}

Besides the results of the analysis developed in this paper, there is a group of U.S. states and countries with high levels of temperature and absolute humidity which have had high growth rate values in their early outbreaks (Table 4). Preliminary data for Brazilian states indicate that, like their U.S. counterparts, warmer and more humid weather have not precluded the expansion of Covid-19. For Amazonas (in the heart of the Amazon rainforest), Ceará and Pernambuco, states with fast early growth of Covid-19 cases, average temperatures were above $27 \mathrm{C}$ and absolute humidity levels above $20 \mathrm{~g} / \mathrm{m}^{3}$, from end of February to early April. Nevertheless, those states are undergoing faster outbreaks of the disease than Southern (colder/drier) states. Thus, any way one looks into the issue, it is hard to argue in favor of the idea that warm and more humid weather would help contain the spread of Covid-19.

Northern hemisphere countries which will be enjoying Summer weather in the coming months, and warm and humid weather countries in Africa, Latin America, North Africa and Southeast Asia, should take that into account as they consider relaxing social distancing measures. It is possible that very high temperatures and levels of absolute humidity would help reduce the speed of Covid-19 spread, but the evidence from our study indicates that the best way to deal with Covid-19, at least until there are vaccines and/or effective therapeutics, taking into account the limitations of existing health systems, is to keep employing adequate levels of social distancing measures, whose results are predicted by modelling (36) and seem to be working effectively in all countries and states that have adopted them. The results on how population density relates to the growth rate of Covid-19 may help calibrate relaxation policies, with special care in the case of high-density communities.

Finally, our study suggests that the analysis of the dynamics of Covid-19 infection, or of any other similar infectious disease, should include population density considerations for subregions within a country or group of countries, which seem to allow for more detailed and complete understanding of the early dynamics of transmission and infection. 
Acknowledgments: the author thanks Profs. Hildete and Aluísio Pinheiro of the Dept. of Statistics at Unicamp for discussions on the statistical aspects of this research. And Simon Schwartzman for observing that population density could be the actual relevant variable, sparking our interest in isolating its effect.

Competing interest: the author declares no competing interests.

Address for correspondence: Renato Pedrosa, Department of Science and Technology Policy, Institute of Geosciences, State University of Campinas (Unicamp). Rua Carlos Gomes, 250. 13085855, Campinas, SP, Brazil; email: pedrosa@uncamp.br

\section{References}

1. Cai, Q-C, J Lu, Q-F Xu, Q Guo, DZ Xu, Q-W Sun, H Yang, G-M Zhao, QW Jiang (2007). Influence of meteorological factors and air pollution on the outbreak of severe acute respiratory syndrome. Public Health 2007; 121: 258-65.

2. Price, RHM, C Graham, S Ramalingam (2019). Association between viral seasonality and meteorological factors. Sci Rep 2019; 9: 1-11.

3. Altamimi A, AE Ahmed. Climate factors and incidence of Middle East respiratory syndrome coronavirus (2019). J Infect Public Health 2019.

4. Sun Z, K Thilakavathy, SS Kumar, G He, SV Liu (2020). Potential Factors Influencing Repeated SARS Outbreaks in China. Int J Environ Res Public Health 2020; 17: 1633.

5. Cohen, J. (2020). Dozens of diseases wax and wane with the seasons. Will Covid-19? Science 2020; 367: 1294-7.

6. Luo, W, MS Majumder, D Liu, C Poirier, KD Mandl, M Lipsitch, M Santillana (2020). The role of absolute humidity on the transmission rates of the Covid-19 outbreak.

https://doi.org/10.1101/2020.02.12.20022467.

7. Sajadi, MM, P Habibzadeh, A Vintzileos, S Shokouhi, F Miralles-Wilhelm, A Amoroso (2020). Temperature, humidity and latitude analysis to predict potential spread and seasonality for Covid-19. http://dx.doi.org/10.2139/ssrn.3550308

8. Bukhari, Q, Y Jameel (2020). Will Coronavirus Pandemic Diminish by Summer? https://papers.ssrn.com/sol3/papers.cfm?abstract id =3556998 (posted 2020/03/19).

9. Ficetola, GF, D Rubolini. 2020. Climate affects global patterns of Covid-19 early outbreak dynamics. https://doi.org/10.1101/2020.03.23.20040501

10. Wang, J, K Tang, K Feng, and W Lu. 2020. High temperature and high humidity reduce the transmission of Covid-19. http://dx.doi.org/10.2139/ssrn.3551767

11. Islam, N, S Shabnam, AM Erzurumluoglu. Temperature, humidity, and wind speed are associated with lower Covid-19 incidence. https://doi.org/10.1101/2020.03.27.20045658

12. Notari, A. Temperature dependence of Covid-19 transmission. https://doi.org/10.1101/2020.03.26.20044529

13. Qi, H, S Xiao, R Shi, MP Ward, Y Chen, W Tu, Q Su1, W Wang, X Wang, Z Zhang (2020). Covid-19 transmission in Mainland China is associated with temperature and humidity: a timeseries analysis. https://doi.org/10.1101/2020.03.30.20044099

14. National Academies of Science, Engineering, Medicine (2020). Rapid Expert Consultation on SARS-CoV-2 Survival in relation to Temperature and Humidity and Potential for Seasonality 
medRxiv preprint doi: https://doi.org/10.1101/2020.04.21.20074450; this version posted May 10, 2020. The copyright holder for this preprint (which was not certified by peer review) is the author/funder, who has granted medRxiv a license to display the preprint in perpetuity.

It is made available under a CC-BY-NC-ND 4.0 International license .

for Covid-19 Pandemic (April 7, 2020). Washington, DC: The National Academies Press. http://nap.edu/25771 https://doi.org/10.17226/25771

15. Rocklöv, J, and H Sjödin. "High population densities catalyze the spread of COVID19." Journal of travel medicine, taaa038. 29 Mar. 2020, doi:10.1093/jtm/taaa03. https://www.ncbi.nlm.nih.gov/pmc/articles/PMC7184409/

16. Liu Y, Gayle AA, Wilder-Smith A, Rocklöv J (2020). The reproductive number of Covid-19 is higher compared to SARS coronavirus. Research Letter, J. Travel Med, 2020, 1-4. doi:10.1093/jtm/taaa021

17. Johns Hopkins Center for Systems Sciences and Engineering. Github CSSEGISandData/Coronavirus site. https://github.com/CSSEGISandData/Covid-19

18. European Centre for Disease Prevention and Control, European Union. https://www.ecdc.europa.eu/en/publications-data/download-todays-data-geographicdistribution-Covid-19-cases-worldwide (downloaded 2020/04/11).

19. National Oceanic and Atmospheric Administration, Integrated Surface Database. https://www.ncdc.noaa.gov/isd (downloaded 2020/04/12).

20. Carslaw, D. Worldmet R software package, Github. https://github.com/davidcarslaw/worldmet

21. Iribarne, JV, WL Godson (2012). Atmospheric Thermodynamics. Springer Science \& Business Media.

22. Bolton, D. The Computation of Equivalent Potential Temperature (1980). Mon. Weather Rev. 108, 1046-1053.

23. County area. https://tigerweb.geo.census.gov/tigerwebmain/TIGERweb counties current.html Access: 2020/04/25

24. County population. https://www.census.gov/data/tables/time-series/demo/popest/2010scounties-total.html\#par textimage Access 2020/04/25

25. Ciccone, A \& RE Hall, 1996. Productivity and the Density of Economic Activity, American Economic Review, AEA, vol. 86(1), pages 54-70, March.

26. Ahlfeldt, GM, E Pietrostefani. The economic effects of density: a synthesis. J Urban Economics 111, 93-107, 2019.

27. Galle, OR, WR Gove, JM McPherson. Population Density and Pathology: What Are the Relations for Man? Science (07 Apr 1972): Vol. 176, Issue 4030, pp. 23-30 DOI: 10.1126/science.176.4030.23. https://science.sciencemag.org/content/176/4030/23

28. Hu H, K Nigmatulina, P Eckhoff. The scaling of contact rates with population density for the infectious disease models. Math. Biosci. 2013; 244(2): 125-34.

https://www.researchgate.net/publication/236691140_The_Scaling_of_Contact_Rates_with_Po pulation Density for the Infectious Disease Models

29. Javan, E., Dr. S. J. Fox,Dr. L. A. Meyers (2020). Probability of current Covid-19 outbreaks in all US counties. https://cid.utexas.edu/sites/default/files/cid/files/Covid-riskmaps counties 4.3.2020.pdf?m=1585958755 (access 2020/04/06).

30. New York Times (2020/04/03), https://www.nytimes.com/interactive/2020/04/03/us/coronavirus-county-epidemics.html

31. Lloyd, AL. The dependence of viral parameter estimates on the assumed viral life cycle: limitations of studies of viral load data. Proc. Biol. Sci. 2001 Apr 22; 268(1469):847-54. https://royalsocietypublishing.org/doi/abs/10.1098/rspb.2000.1572

32. Lipsitch, M, T Cohen, B Cooper, JM Robins, S Ma, L James, et al. Transmission Dynamics and Control of Severe Acute Respiratory Syndrome. Science (20 Jun 2003): Vol. 300, Issue 5627, pp. 1966-1970. DOI: 10.1126/science. 1086616 https://science.sciencemag.org/content/300/5627/1966 
medRxiv preprint doi: https://doi.org/10.1101/2020.04.21.20074450; this version posted May 10, 2020. The copyright holder for this preprint (which was not certified by peer review) is the author/funder, who has granted medRxiv a license to display the preprint in perpetuity.

It is made available under a CC-BY-NC-ND 4.0 International license .

33. Li, Q, M Med, X Guan, P Wu, X Wang, L Zhou et al. Early transmission dynamics in Wuhan, China, of novel coronavirus-infected pneumonia. N Engl J Med 2020. 382:1199-1207. DOI: 10.1056/NEJMoa2001316

34. Sanche, S, YT Lin, C Xu, E Romero-Severson, N Hengartner, R Ke (2020). High contagiousness and rapid spread of severe acute respiratory syndrome coronavirus 2. Emerg Infect Dis, 2020/July. https://doi.org/10.3201/eid2607.200282

35. Pedrosa, R. Population density and infection timeline effects on the initial growth rate of Covid19 cases and deaths in U.S. counties. In preparation.

36. Bendtsen Cano, O, S Cano Morales, C Bendtsen. (2020) Covid-19 Modelling: the Effects of Social Distancing. https://doi.org/10.1101/2020.03.29.20046870 
medRxiv preprint doi: https://doi.org/10.1101/2020.04.21.20074450; this version posted May 10,2020 . The copyright holder for this preprint (which was not certified by peer review) is the author/funder, who has granted medRxiv a license to display the preprint in perpetuity.

It is made available under a CC-BY-NC-ND 4.0 International license.

\section{Tables}

Table 1. Regression models for U.S. states. All models exclude CA, MA, NY, WA (see text). Coefficient interval: $95 \% \mathrm{CI}$ estimate. $R^{2}$ for model 4 is the adjusted value.

\begin{tabular}{|c|c|c|c|c|c|c|c|c|c|}
\hline Case & $\begin{array}{l}\text { Depend } \\
\text { variable }\end{array}$ & $\begin{array}{l}\text { Control } \\
\text { variable(s) }\end{array}$ & Coeff. & $p$-value & SE & $\begin{array}{c}\text { Coefficient } \\
\text { interval } \\
\text { variation }\end{array}$ & $R^{2}$ & $\begin{array}{l}\text { F-stat } \\
p \text {-value }\end{array}$ & $\begin{array}{c}\text { Shap-Wilk } \\
\text { p-value } \\
\text { (residuals) }\end{array}$ \\
\hline & & $A v T$ & 0.0026 & 0.2781 & 0.0023 & \pm 0.0047 & & & \\
\hline & & AvAH & -0.0056 & 0.2292 & 0.0045 & \pm 0.0093 & & & \\
\hline & & Day $_{100}$ & -0.0073 & 0.0013 & 0.0021 & \pm 0.0043 & & & \\
\hline & & $\log (D P)$ & 0.0228 & 0.0015 & 0.0067 & \pm 0.0136 & & & \\
\hline \multirow{3}{*}{2} & \multirow{3}{*}{$k$} & $A v T$ & $<0.0001$ & 0.9805 & 0.0010 & \pm 0.0020 & & & \\
\hline & & Day $_{100}$ & -0.0080 & 0.0004 & 0.0021 & \pm 0.0043 & & & \\
\hline & & $\log (D P)$ & 0.0213 & 0.0026 & 0.0066 & \pm 0.0132 & & & \\
\hline \multirow{3}{*}{3} & \multirow{3}{*}{$k$} & $A v A H$ & -0.0010 & 0.5983 & 0.0019 & \pm 0.0038 & & & \\
\hline & & Day100 & -0.0080 & $<0.001$ & 0.0020 & \pm 0.0040 & & & \\
\hline & & $\log (D P)$ & -0.0219 & 0.0021 & 0.0067 & \pm 0.0135 & & & \\
\hline \multirow{2}{*}{4} & \multirow{2}{*}{$k$} & Day $_{100}$ & -0.0080 & 0.0003 & 0.0020 & \pm 0.0040 & \multirow{2}{*}{0.7106} & \multirow{2}{*}{$<0.001$} & \multirow{2}{*}{0.8350} \\
\hline & & $\log (D P)$ & 0.0212 & 0.0022 & 0.0065 & \pm 0.0130 & & & \\
\hline 5 & $k$ & $A v T$ & 0.0038 & 0.0217 & 0.0016 & \pm 0.0032 & 0.1140 & & 0.6408 \\
\hline 6 & $k$ & $A v A H$ & 0.0053 & 0.1090 & 0.0033 & \pm 0.0066 & 0.0573 & & 0.6225 \\
\hline 7 & $k$ & $D_{10 y} 100$ & -0.0130 & $<0.001$ & 0.0014 & \pm 0.0028 & 0.6550 & & 0.8590 \\
\hline 8 & $k$ & $\log (D P)$ & 0.0410 & $<0.001$ & 0.0048 & \pm 0.0097 & 0.6220 & & 0.9155 \\
\hline 9 & $D_{10}{ }_{100}$ & $\log (D P)$ & -2.4889 & $<0.001$ & 0.3139 & \pm 0.6300 & 0.5883 & & 0.4401 \\
\hline
\end{tabular}

Table 2. Regression models for countries. Coefficient interval: 95\% CI estimate.

\begin{tabular}{|c|c|c|c|c|c|c|c|c|c|}
\hline Case & $\begin{array}{l}\text { Depend } \\
\text { variable }\end{array}$ & $\begin{array}{l}\text { Control } \\
\text { Variable(s) }\end{array}$ & Coeff. & $p$-value & SE & $\begin{array}{c}\text { Coefficient } \\
\text { Interval } \\
\text { variation }\end{array}$ & $R^{2 *}$ & $\begin{array}{c}\text { F-stat } \\
p \text {-value }\end{array}$ & $\begin{array}{c}\text { Shap-Wilk } \\
\text { p-value } \\
\text { (residuals) }\end{array}$ \\
\hline \multirow[t]{3}{*}{1} & \multirow[t]{3}{*}{$k$} & $A v T$ & 0.0004 & 0.8068 & 0.0016 & \pm 0.0032 & & & \\
\hline & & $A v A h$ & 0.0010 & 0.6965 & 0.0025 & \pm 0.0050 & & & \\
\hline & & Day $_{100}$ & -0.0045 & $<0.001$ & 0.0006 & \pm 0.0012 & & & \\
\hline \multirow[t]{3}{*}{$1^{\dagger}$} & \multirow[t]{3}{*}{$k$} & $A v T$ & 0.0003 & 0.8611 & 0.0016 & \pm 0.0032 & & & \\
\hline & & $A v A h$ & -0.0009 & 0.7945 & 0.0025 & \pm 0.0049 & & & \\
\hline & & Day $_{100}$ & -0.0051 & $<0.001$ & 0.0007 & \pm 0.0014 & & & \\
\hline \multirow{2}{*}{2} & \multirow{2}{*}{$k$} & $A v A H$ & -0.0022 & 0.0583 & 0.0011 & \pm 0.0022 & \multirow{2}{*}{0.3381} & \multirow{2}{*}{$<0.001$} & \multirow{2}{*}{0.8966} \\
\hline & & Day $_{100}$ & 0.0041 & $<0.001$ & 0.0006 & \pm 0.0012 & & & \\
\hline \multirow{2}{*}{$2^{\dagger}$} & \multirow{2}{*}{$k$} & $A v A H$ & -0.0021 & 0.0643 & 0.0011 & \pm 0.0022 & \multirow{2}{*}{0.3259} & \multirow{2}{*}{$<0.001$} & \multirow{2}{*}{0.7253} \\
\hline & & Day $_{100}$ & 0.0047 & $<0.001$ & 0.0007 & \pm 0.0014 & & & \\
\hline 3 & $k$ & AvTemp & -0.0026 & 0.0020 & 0.0008 & \pm 0.0016 & 0.0853 & & 0.0045 \\
\hline 4 & $k$ & $A v A h$ & -0.0042 & 0.0014 & 0.0013 & \pm 0.0025 & 0.0910 & & 0.0010 \\
\hline 5 & $k$ & Day $_{100}$ & -0.0045 & $<0.001$ & 0.0006 & \pm 0.0012 & 0.3280 & & 0.8427 \\
\hline $5^{\dagger}$ & $k$ & $\operatorname{Day}_{100}$ & -0.0051 & $<0.001$ & 0.0007 & \pm 0.0014 & 0.3166 & & 0.3170 \\
\hline
\end{tabular}

* Adjusted $R^{2}$ for multivariable models

${ }^{\dagger}$ Omits China (see text) 
medRxiv preprint doi: https://doi.org/10.1101/2020.04.21.20074450; this version posted May 10, 2020. The copyright holder for this preprint (which was not certified by peer review) is the author/funder, who has granted medRxiv a license to display the preprint in perpetuity.

It is made available under a CC-BY-NC-ND 4.0 International license.

Table 3. Regression of adjusted $k$ in terms of $(\log )$ population density, U.S. states.

\begin{tabular}{cccccccc}
\hline & Estimate & SE & p-value & $\begin{array}{c}\text { Inferior } \\
\text { value (95\%) }\end{array}$ & $\begin{array}{c}\text { Superior } \\
\text { value (95\%) }\end{array}$ & $\boldsymbol{R}^{\mathbf{2}}$ & $\begin{array}{c}\text { Shapiro-Wilk } \\
\text { p-value }\end{array}$ \\
\hline Constant & 0.2135 & 0.0224 & $<0.001$ & 0.1684 & 0.2585 & & \\
\cline { 1 - 6 } Coefficient & 0.0212 & 0.0041 & $<0.001$ & 0.0129 & 0.0296 & & 0.3756 \\
\hline
\end{tabular}

Table 4. States/countries with $k>0.200$ and average temperature $>20 \mathrm{C}$ or average absolute humidity $>10 \mathrm{~g} / \mathrm{m}^{3} . R^{2}$ of exponential regressions (Eq. 3), dates of $1^{\text {st }}\left(\right.$ Day $\left._{1}\right)$ and of $100^{\text {th }}$ case $\left(\right.$ Day $\left._{100}\right)$.

\begin{tabular}{llcccccc}
\hline State/Country & Region & AvTemp & AvAH & $\boldsymbol{k}$ & $\boldsymbol{R}^{\mathbf{2}}$ & Day1 & Day100 \\
\hline Florida & USA & 23.9 & 13.4 & 0.319 & 0.972 & $2020-03-02$ & $2020-03-15$ \\
\hline Brazil & Americas & 23.2 & 16.6 & 0.307 & 0.993 & $2020-02-26$ & $2020-03-15$ \\
\hline Louisiana & USA & 21.7 & 14.1 & 0.295 & 0.982 & $2020-03-11$ & $2020-03-16$ \\
\hline Ecuador & Americas & 19.8 & 10.1 & 0.291 & 0.974 & $2020-03-01$ & $2020-03-18$ \\
\hline Texas & USA & 16.9 & 11.3 & 0.269 & 0.962 & $2020-03-05$ & $2020-03-17$ \\
\hline Nigeria & SubSahAf & 29.1 & 20.2 & 0.261 & 0.981 & $2020-02-28$ & $2020-03-31$ \\
\hline South Africa & SubSahAf & 18.3 & 10.1 & 0.259 & 0.993 & $2020-03-06$ & $2020-03-19$ \\
\hline Thailand & Asia/Pacific & 29.4 & 19.1 & 0.248 & 0.942 & $2020-01-13$ & $2020-03-16$ \\
\hline Alabama & USA & 17.7 & 11.0 & 0.243 & 0.985 & $2020-03-13$ & $2020-03-20$ \\
\hline Malaysia & Asia/Pacific & 29.1 & 21.1 & 0.233 & 0.952 & $2020-01-25$ & $2020-03-10$ \\
\hline Dominican Rep. & Americas & 23.7 & 17.9 & 0.220 & 0.887 & $2020-03-02$ & $2020-03-22$ \\
\hline Chile & Americas & 21.1 & 8.8 & 0.220 & 0.992 & $2020-03-04$ & $2020-03-17$ \\
\hline Saudi Arabia & MEast-NAfr & 21.5 & 5.4 & 0.220 & 0.977 & $2020-03-03$ & $2020-03-16$ \\
\hline Panama & Americas & 29.9 & 18.5 & 0.219 & 0.993 & $2020-03-10$ & $2020-03-18$ \\
\hline Indonesia & Asia/Pacific & 27.7 & 21.1 & 0.211 & 0.978 & $2020-03-02$ & $2020-03-16$ \\
\hline New Zealand & Asia/Pacific & 17.8 & 11.2 & 0.210 & 0.979 & $2020-02-28$ & $2020-03-23$ \\
\hline Argentina & Americas & 22.6 & 14.8 & 0.201 & 0.995 & $2020-03-04$ & $2020-03-20$ \\
\hline Australia & Asia/Pacific & 21.7 & 13.6 & 0.200 & 0.994 & $2020-01-25$ & $2020-03-10$ \\
\hline India & Asia/Pacific & 21.3 & 11.8 & 0.200 & 0.983 & $2020-01-30$ & $2020-03-17$ \\
\hline & & & & & & & \\
\hline
\end{tabular}


medRxiv preprint doi: https://doi.org/10.1101/2020.04.21.20074450; this version posted May 10, 2020. The copyright holder for this preprint (which was not certified by peer review) is the author/funder, who has granted medRxiv a license to display the preprint in perpetuity.

It is made available under a CC-BY-NC-ND 4.0 International license .

\section{Figures}

Figure 1.a-g. - Boxplots for regression variables and for $R^{2}$ for the exponential regression for $k$ (Eq. 3). U.S. states, by region. Data: CESS/JHU, NOAA/USDC, U.S. Census (2010).
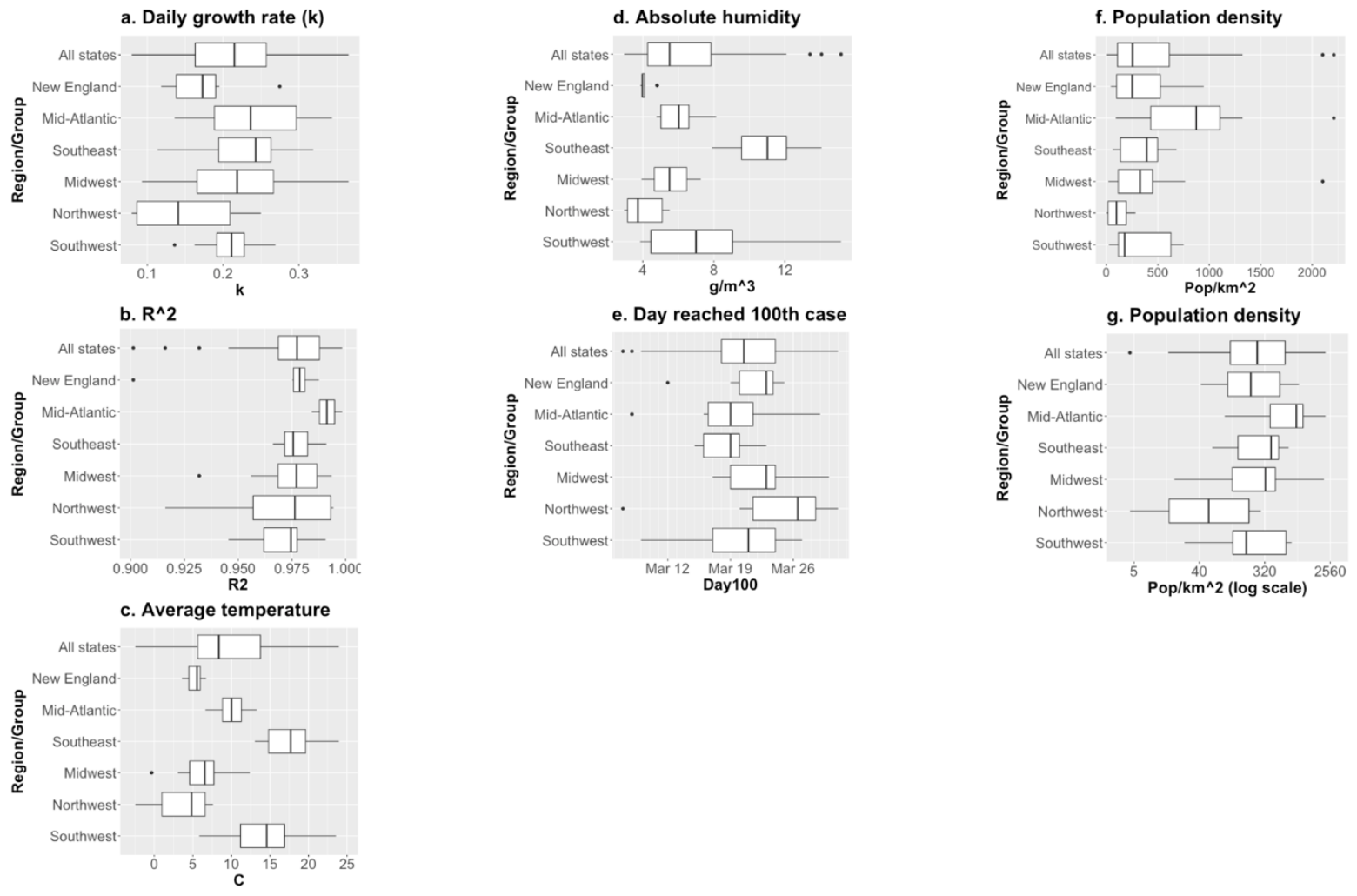

Figure 2.a-e. - Boxplots for regression variables and for $R^{2}$ for the exponential regression for $k$ (Eq. 3). Countries, by region. Data: ECDC/EU, NOAA/USDC.
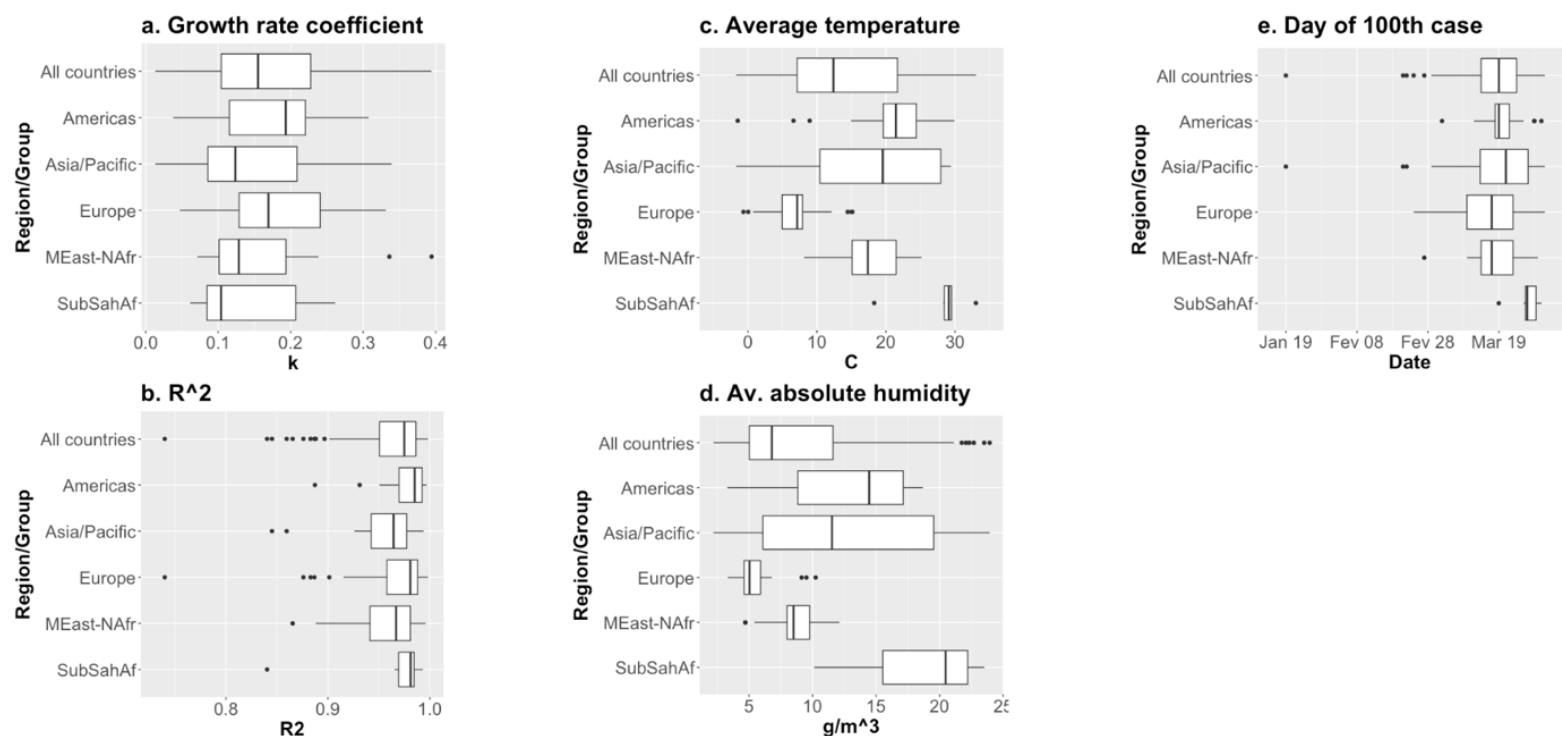
medRxiv preprint doi: https://doi.org/10.1101/2020.04.21.20074450; this version posted May 10, 2020. The copyright holder for this preprint (which was not certified by peer review) is the author/funder, who has granted medRxiv a license to display the preprint in perpetuity.

It is made available under a CC-BY-NC-ND 4.0 International license .

Figure 3.a-d - Number of cases and evolution of $k$, computed using a 10-day moving window. States with early outbreaks $\left(100^{\text {th }}\right.$ case on or before March $\left.12^{\text {th }}\right)$. Values of $k$ marked on the first day of 10-day window. Graph for New York includes the two counties with most cases in the 10-window period used to compute the estimate of $k$ for the state. All graphs include the points for date when state reached the $100^{\text {th }}$ case. Point of maximum also annotated for $k$ curves. Data: CSSE/JHU.
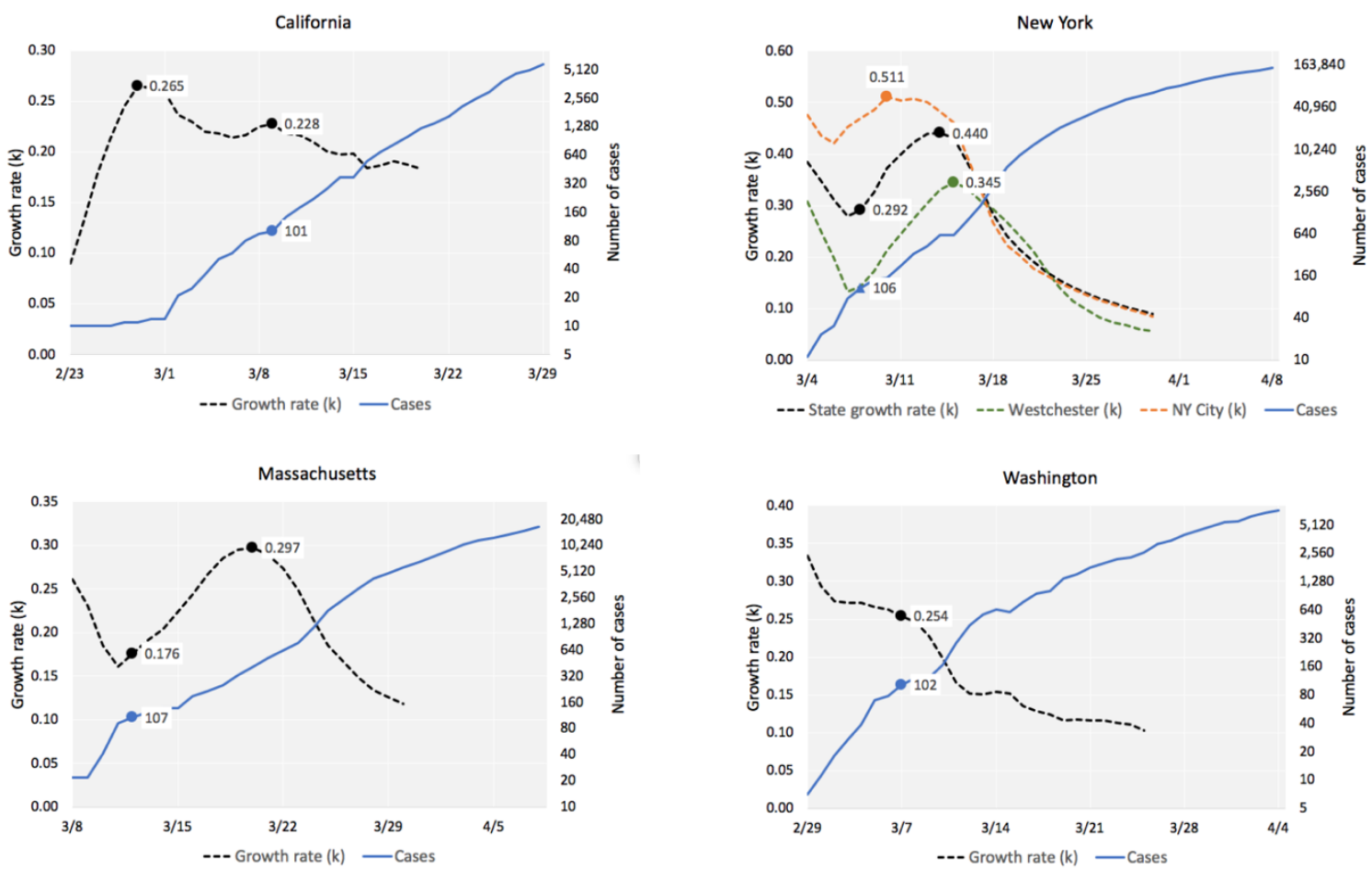

Figure 4 - Actual and regressed (Eq. 3) curves of number of confirmed cases, selected countries, 10 days starting on the day of $100^{\text {th }}$ case. Values of $k$ and $R^{2}$ for the regressed exponentials. Data: ECDC/EU.

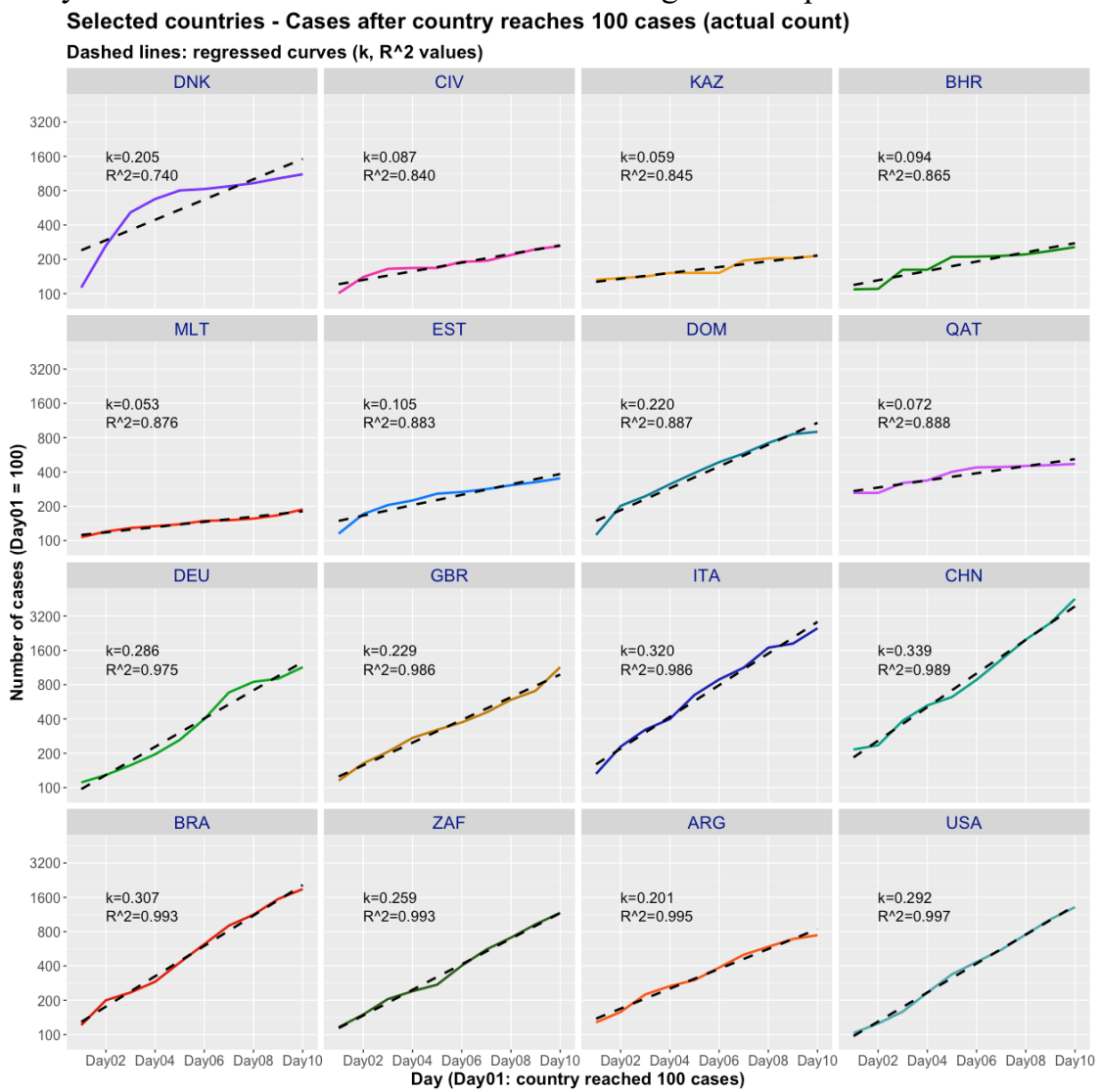


medRxiv preprint doi: https://doi.org/10.1101/2020.04.21.20074450; this version posted May 10, 2020. The copyright holder for this preprint (which was not certified by peer review) is the author/funder, who has granted medRxiv a license to display the preprint in perpetuity.

It is made available under a CC-BY-NC-ND 4.0 International license .

Figure 5.a-d: Daily average temperature and absolute humidity, U.S. states and countries. Period of 25 days, starting 15 days before state/country reached $100^{\text {th }}$ case. Data: NOAA/USDC, CSSEC/Johns Hopkins, ECDC/EU.

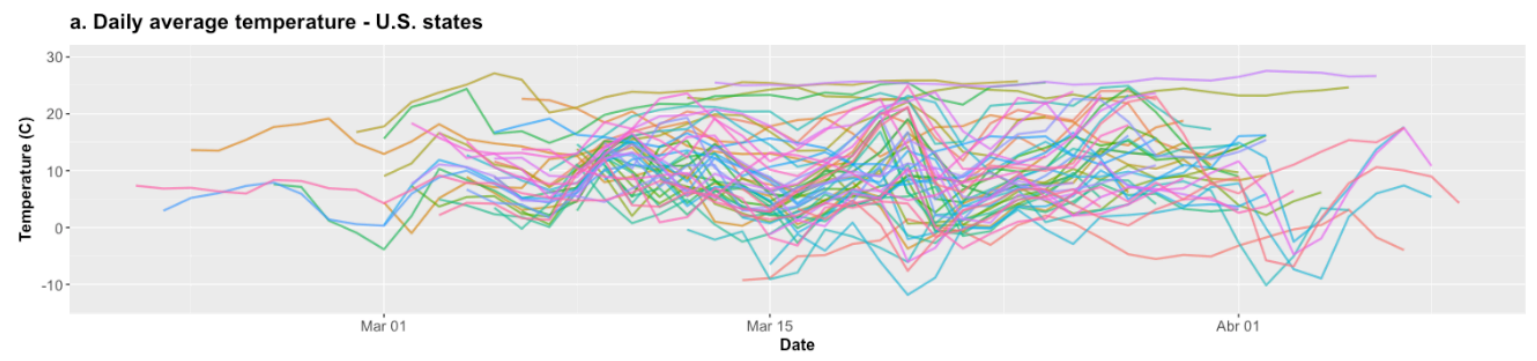

b. Daily average absolute humidity - U.S. states
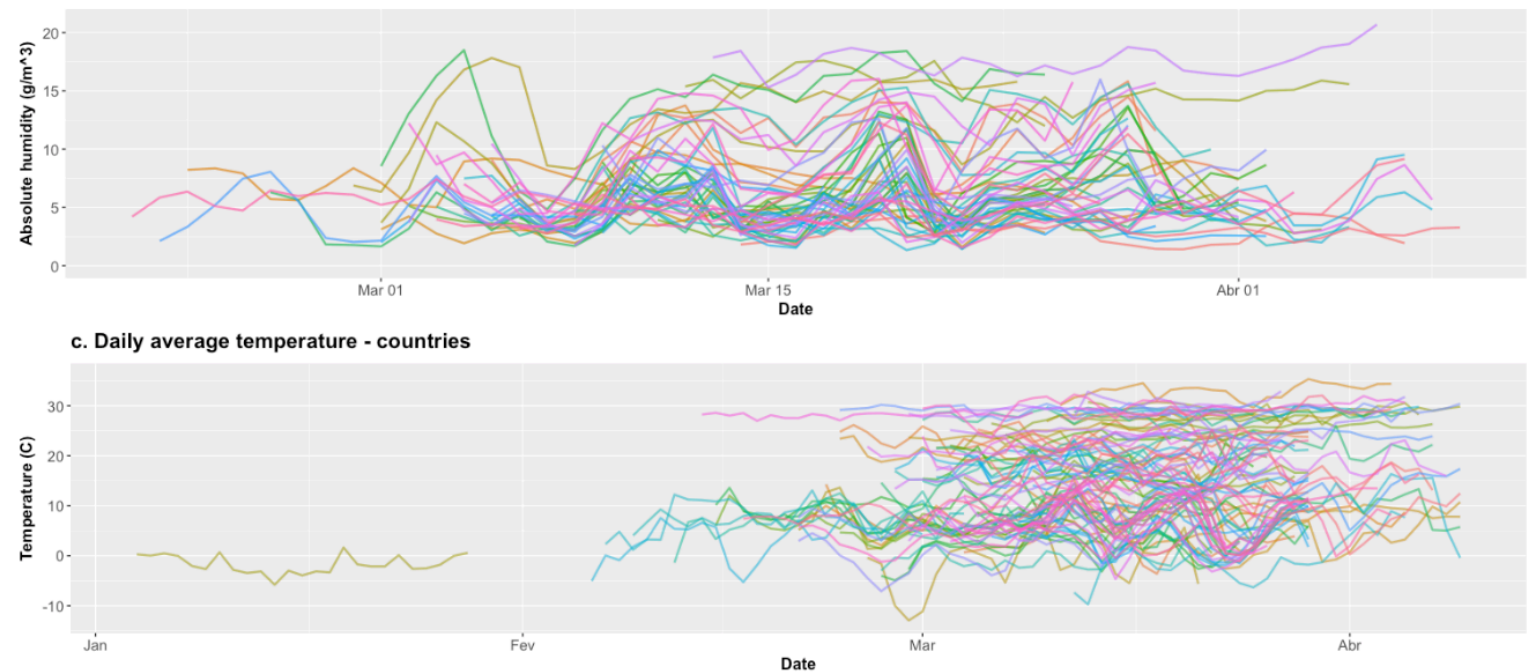

d. Daily average absolute humidity - countries

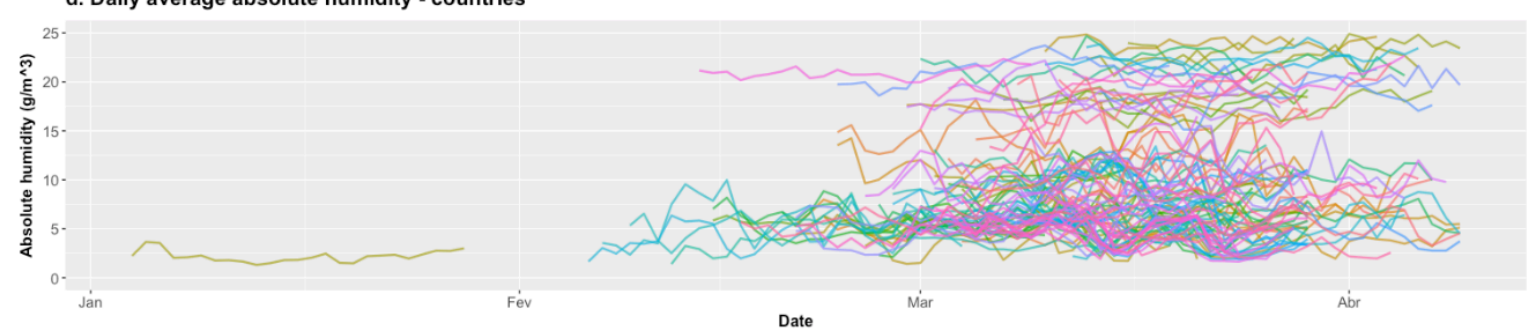

Figure 6.a-b - Average temperature and absolute humidity, exponential trend lines: a. U.S. states, b. countries. Parameters and trend lines have excluded states and country in orange (Burkina Faso) (see text). Data: NOAA/USDC.
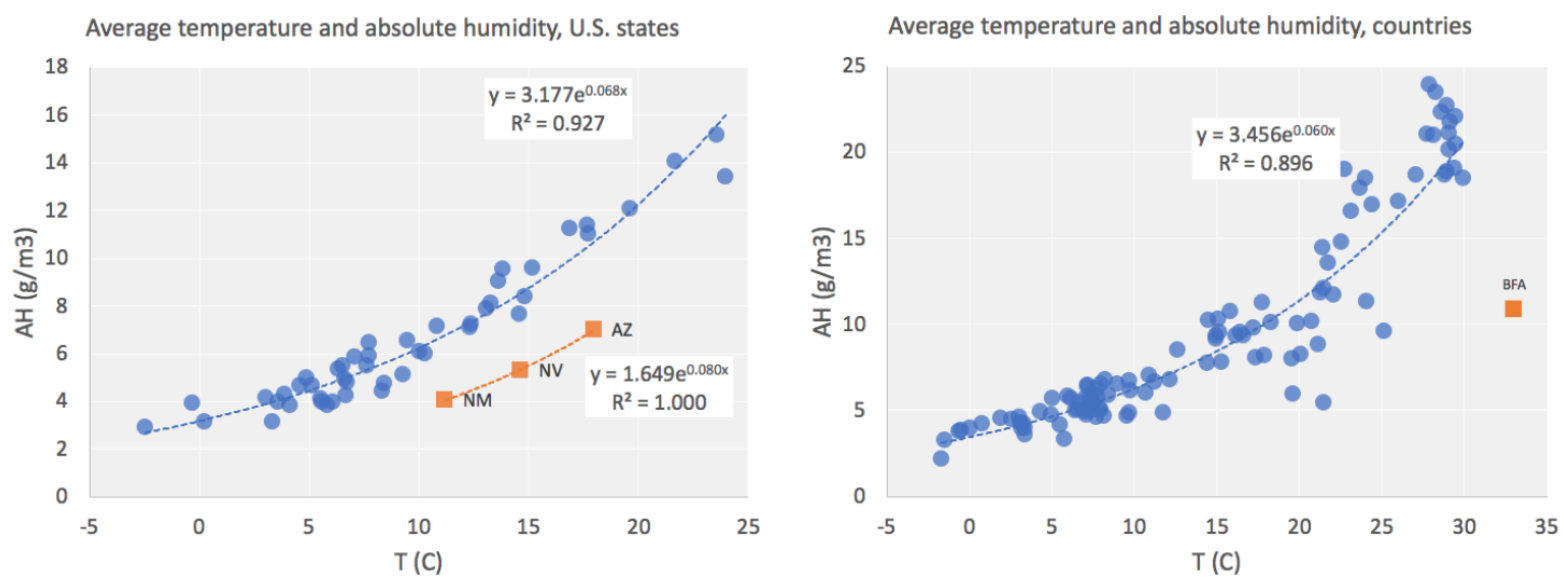
medRxiv preprint doi: https://doi.org/10.1101/2020.04.21.20074450; this version posted May 10, 2020. The copyright holder for this preprint (which was not certified by peer review) is the author/funder, who has granted medRxiv a license to display the preprint in perpetuity.

It is made available under a CC-BY-NC-ND 4.0 International license .

Figure 7.a-d - Scatter plots of weather variables and date of $100^{\text {th }}$ case, U.S. states and countries. Data: CSSE/JHU, ECDC/EU, NOAA/USDC.
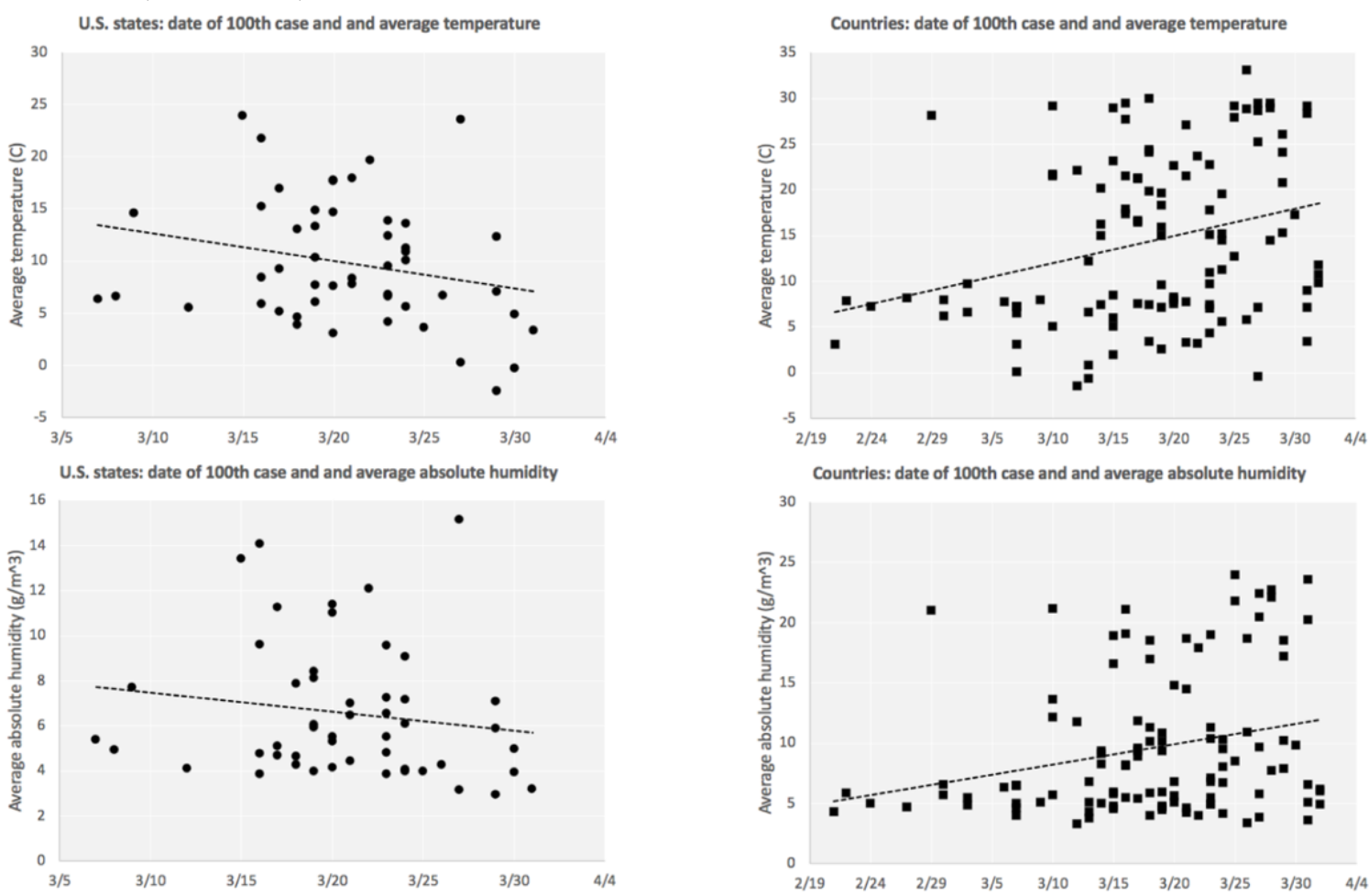

Figure 8 - Number of confirmed cases for 10 days starting when U.S. state reached 100 cases (normalized count, Day01 = 100), by temperature. Dotted lines: exponential curves with number of days to double the number of cases and value of $k$. Data: CSSE/JHU, NOAA/USDC.

\section{U.S. states: evolution and temperature}

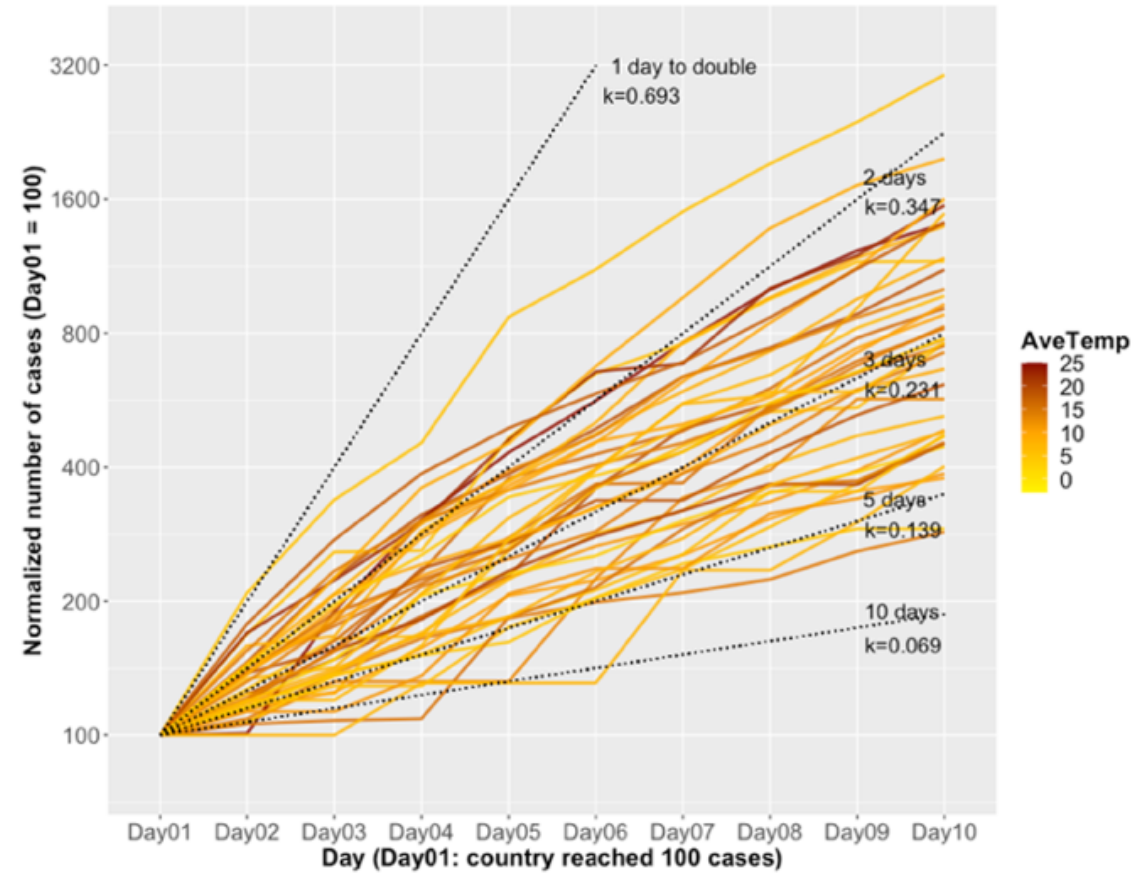


medRxiv preprint doi: https://doi.org/10.1101/2020.04.21.20074450; this version posted May 10, 2020. The copyright holder for this preprint (which was not certified by peer review) is the author/funder, who has granted medRxiv a license to display the preprint in perpetuity.

It is made available under a CC-BY-NC-ND 4.0 International license.

Figure 9.a-d - Scatter plots of exponential growth rate $(k)$ and control variables, U.S. states. Regression parameters and line omit CA, MA, NY, WA (see text) Data: CSSE/JHU, NOAA/USDC, U.S. Census (2010).
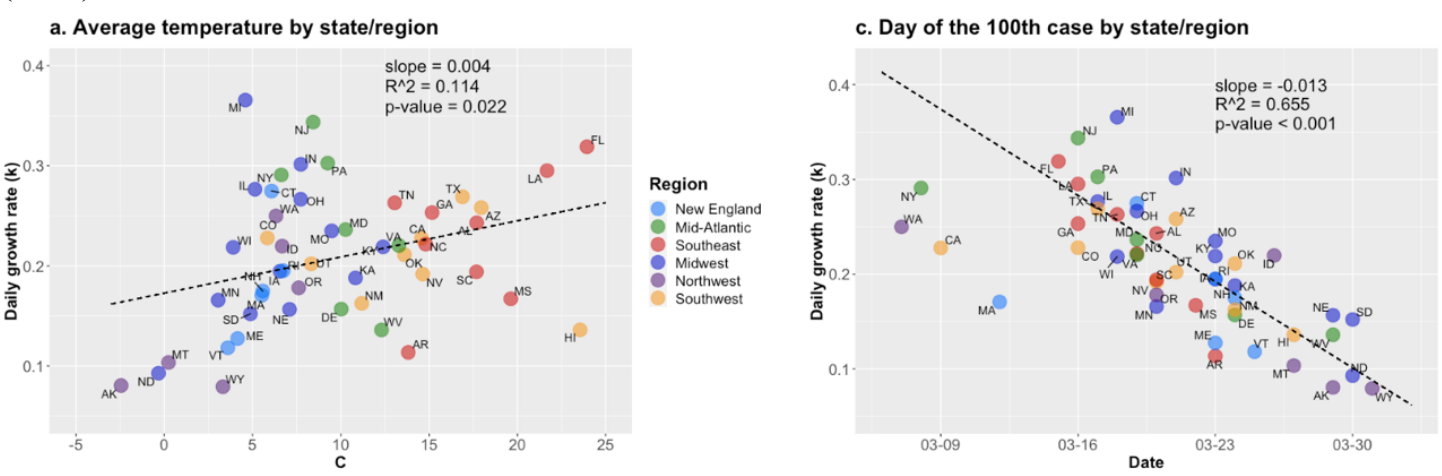

Regio
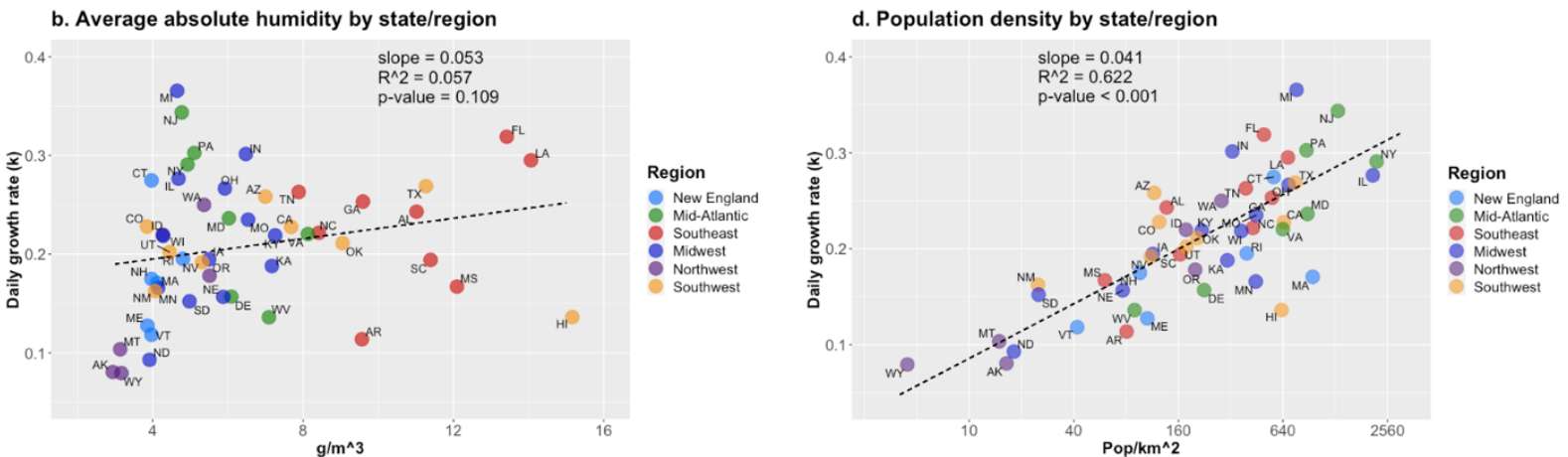

Figure 10 - Scatter plot of date of $100^{\text {th }}$ case and population density, U.S. states. Regression parameters and line omit CA, MA, NY, WA (see text). Data: CSSE/JHU, U.S. Census (2010).

Date of 100th case and population density

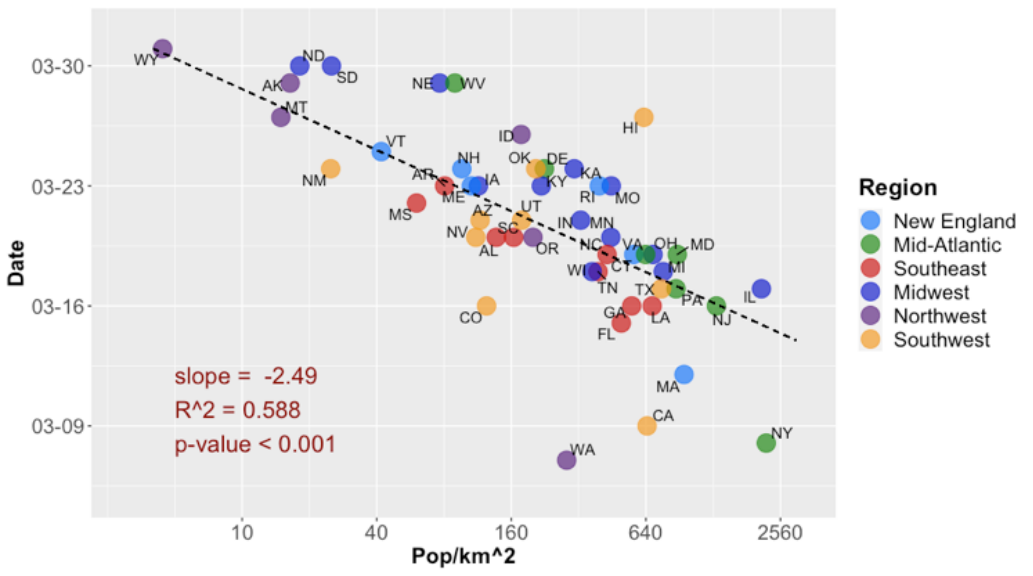


medRxiv preprint doi: https://doi.org/10.1101/2020.04.21.20074450; this version posted May 10, 2020. The copyright holder for this preprint (which was not certified by peer review) is the author/funder, who has granted medRxiv a license to display the preprint in perpetuity.

It is made available under a CC-BY-NC-ND 4.0 International license .

Figure 11.a-c - Scatter plots, exponential growth rate $(k)$ and control variables. Countries. Plot c. omits China (see text). Data: ECDC/EU, NOAA/USDC.
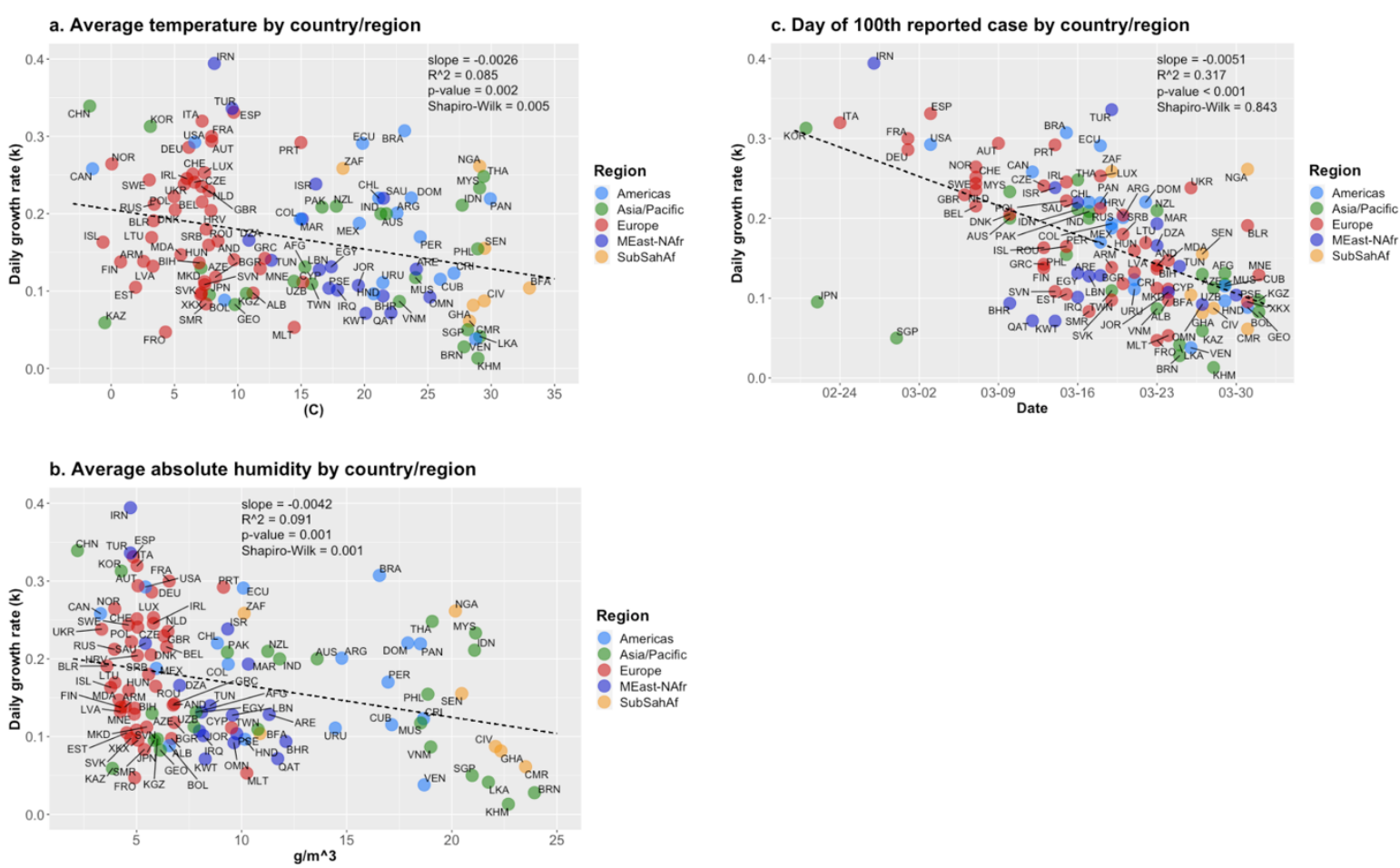

Figure 12 - Adjusted initial daily growth rate and population density. 95\% CI band between dashed lines. See text for the four states in red.

Adjusted initial daily growth rate and population density, U.S. states

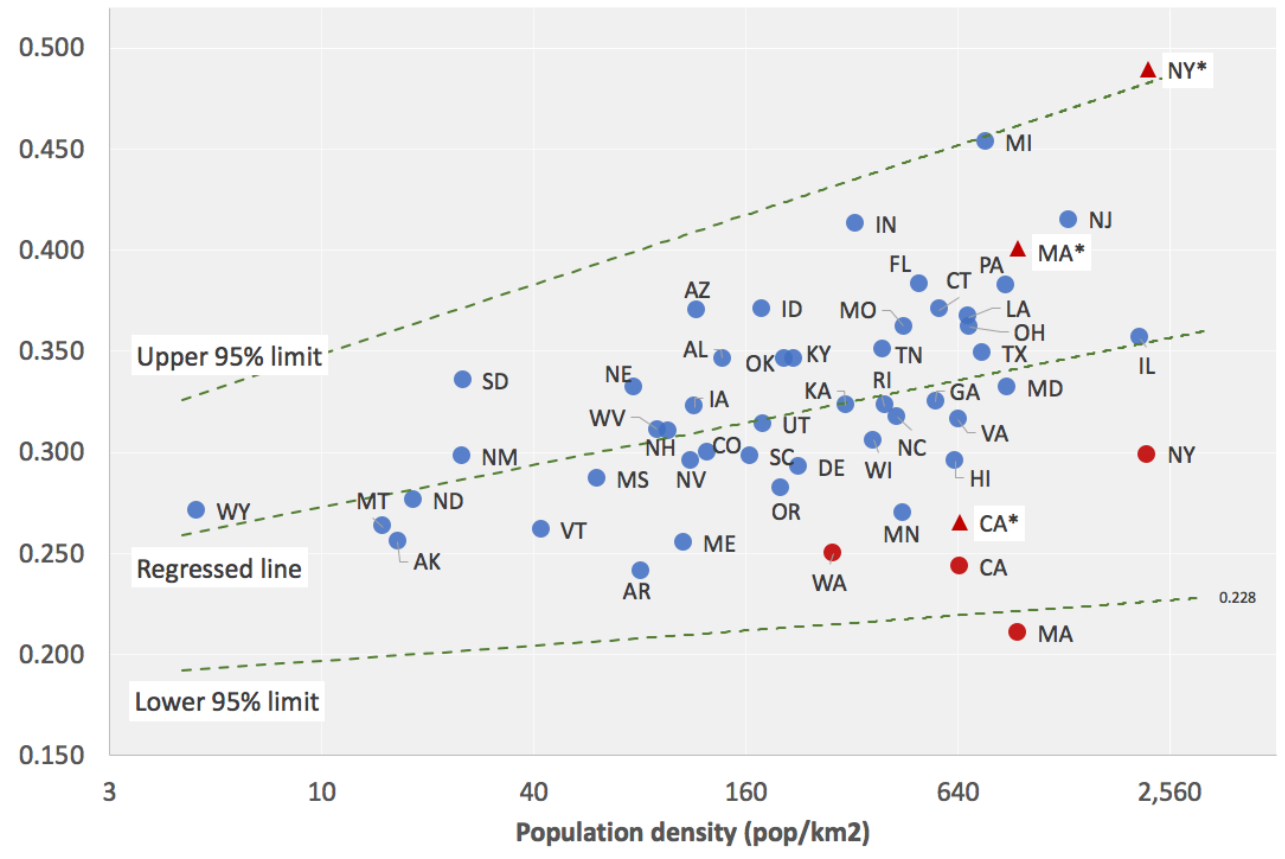

